\title{
Comparison of the effectiveness of topical silicone gel and corticosteroid cream on the pfannenstiel scar prevention - a randomized controlled trial
}

\author{
Elif Meseci ${ }^{1}$, Semra Kayatas ${ }^{2}$, Murat Api ${ }^{3}$, Aysen Boza ${ }^{4}$, Muzaffer Seyhan Cikman² \\ ${ }^{1}$ Department of Obstetrics and Gynecology, Acıbadem Kozyatagı Hospital, Istanbul, Turkey \\ ${ }^{2}$ Department of Obstetrics and Gynecology, Zeynep Kamil Maternity and Children's Diseases Training \\ and Research Hospital, Istanbul, Turkey \\ ${ }^{3}$ Department of Obstetrics and Gynecology, Faculty of Medicine, Medipol University, Istanbul, Turkey \\ ${ }^{4}$ Department of Obstetrics and Gynecology,VKV American Hospital, Istanbul, Turkey
}

\begin{abstract}
Objectives: To compare the effects of topical silicone gel and corticosteroid cream for preventing hypertrophic scar and keloid formation following Pfannenstiel incisions.

Material and methods: Fifty patients operated for benign gynecological diseases through primary Pfannenstiel incision were included. The wounds were randomly allocated to the treatment and control arms. In the treatment arm, the wounds were divided into two halves; one was treated with silicone gel and the other with methylprednisolone cream. No treatment was administered to the control group. Scars using the modified Vancouver Scar Scale (MVSS), patient satisfaction, and side effects were evaluated before and after $\left(3^{\text {rd }}\right.$ month when treatment discontinued and $6^{\text {th }}$ month) the treatment.

Results: Thirty-nine patients (21 patients in the treatment group and 18 patients in the control group) completed the study. Intragroup comparisons of the $3^{\text {rd }}$ month and $6^{\text {th }}$ month scores of the MVSS revealed that the scores of all parameters (height, pigmentation, vascularity, pliability, and total MVSS score) significantly decreased at the $6^{\text {th }}$ month evaluation as compared with the $3^{\text {rd }}$ month evaluation in all groups (control, silicone, and methylprednisolone groups). Multiple group comparisons at the $6^{\text {th }}$ month revealed that the most prominent improvements occurred in the methylprednisolone group in all MVSS parameters as compared with the control group and in the height, vascularity, and pigmentation parameters as compared with the silicone group. No side effects were experienced by the patients with either treatment and patient satisfaction was higher in the methylprednisolone group.

Conclusion: The use of topical methylprednisolone cream in fresh wounds at the postoperative early period appears to be promising.
\end{abstract}

Key words: cicatrix, methyl prednisolonate, silicone gel, topical administration, wound healing

Ginekologia Polska 2017; 88, 11:591-598

\section{INTRODUCTION}

Skin incisions may result in scar formation. Pathological cutaneous scars such as keloids and hypertrophic scars (HS) occur due to general failure of normal wound healing processes. These scars are usually characterized by inflammation, excessive fibroblast proliferation, and abnormal deposition of extracellular matrix proteins [1]. Both HS and keloids usually develop within 1 to 3 months after an injury, trauma, or surgical incision [2].
Several treatments and prophylactic modalities including surgical excision, radiation, pressure therapy, cryotherapy, topical silicone gel, intralesional injections of corticosteroids, laser treatment, and various medications have been used in the management of HS and keloids [3-6]. Silicone gel sheeting and intralesional cortisone injection have been suggested as effective prevention and treatment of HS and keloids [7, 8]. Recent studies offer that topical agents might be effective first-line options for non-invasive treatment of these scars [9]. 


\section{OBJECTIVES}

The aim of this study was to compare the effectiveness of topical silicone gel and topical corticosteroid cream for preventing postoperative HS and keloids resulting from Pfannenstiel incision following gynecological operations.

\section{MATERIAL AND METHODS}

The present prospective, randomized, controlled study was conducted between January 2014-December 2014 in Zeynep Kamil Maternity and Children's Diseases Training and Research Hospital, Istanbul, Turkey. This study followed the Declaration of Helsinki and was approved by Ethics Committee of our hospital. All patients were informed about the study and provided written consents.

Fifty patients undergone operation for benign gynecological diseases through a primary Pfannenstiel incision were included. These patients aged 28-52 years and had Fitzpatrick skin type II-V. The wound closures were performed using the same procedure by the same surgeon. Patients with a history of HS or keloids, those having any previous abdominal incisions, systemic infection, patients having chronic medical illnesses that might affect wound healing (diabetes mellitus, renal failure, hematological diseases), a known hypersensitivity/allergy to any medication used in the study, those using certain systemic treatments within the last 6 months (such as cortisone, anti-inflammatory drugs) were excluded from the study.

After confirming normal epithelialization and wound healing on the incision site at the $10^{\text {th }}$ postoperative day, patients who met the selection criteria were randomised to the treatment group or control group. In the treatment group ( $n=25)$, the wound was divided into two halves; one half was treated with silicone gel (Dermatix ${ }^{\oplus}$; Hanson Medical Inc., Kingston, WA, USA) and the other half with methylprednisolone cream (Advantan ${ }^{\circledast}$; Intendis GmbH, Germany). Silicone gel was applied twice a day and the corticosteroid cream in every other 2 days to prevent skin atrophy. The treatment duration was 3 months. No treatment was administered to the control group $(n=25)$. Funding was supported by the researchers on their own. A blinded dermatologist performed the follow-up examinations before treatment (at baseline, i.e., at the $10^{\text {th }}$ postoperative day), after treatment (at the end of the $3^{\text {rd }}$ month), and 3 months after discontinuation of treatment (at the end of the $6^{\text {th }}$ month). During the follow-up period, 4 patients from the treatment group and 7 patients from the control group dropped out because of personal reasons. Finally, 39 patients ( 21 patients in the treatment group and 18 patients in the control group) were analyzed at the end of the $6^{\text {th }}$-month follow-up period.

Scar assessment was performed using the modified Vancouver Scar Scale (MVSS) by assessing scar pigmentation (0 - normal color, 1 - hypopigmentation, $2-$ hy- perpigmentation), vascularity (0 - normal color, 1 - pink, 2 - pink to red, 3 - red, 4 - red to purple, 5 - purple), pliability ( 0 - normal, 1 - supple, 2 - yielding, 3 - firm, 4 - banding-rope tissue, 5 - contracture), and height (0 - normal/flat, 1: < $2 \mathrm{~mm}, 2: 2-5 \mathrm{~mm}, 3:>5 \mathrm{~mm}$ ) [10]. In the present study, a linear probe ultrasound (Mindray DC6, $5.0-7.5 \mathrm{mHz}$, China) was used to measure the scar thickness. A blinded radiologist performed the assessments.

In the present study, the side effects experienced by the patients were also assessed every 2 months. At the 6-month follow-up, the patients were asked to rate their satisfaction using a 4-point grading scale ( 1 = unsatisfied, 2 = slightly satisfied, 3 = satisfied, 4 = very satisfied) for each group.

\section{Statistical analysis}

All statistical analyses were performed using SPSS Statistics for Windows, version 20.0. (IBM Corp., Armonk, NY, USA). Data are expressed as mean, standard deviation, median and $25^{\text {th }}(\mathrm{Q} 1)$ and $75^{\text {th }}(\mathrm{Q} 3)$ percentiles. For non-normally distributed variables, two group comparisons were performed using the Mann-Whitney $U$ test. Multiple group comparisons of non-normally distributed data were performed using the Kruskal-Wallis test, which was followed by post hoc analysis. Moreover, Wilcoxon signed-rank test was used to compare the $3^{\text {rd }}$ and $6^{\text {th }}$ month values. A p value of $<0.05$ was considered statistically significant.

\section{RESULTS}

In the present study, 39 patients were analyzed. The patient flowchart is presented in Figure 1. Comparison of age and body mass index (BMI) values and scar assessment scores based on MVSS at baseline between the control and treatment groups are presented in Table 1. There was no significant difference between the control and treatment groups regarding age, BMI values, and MVSS scores. All patients ( $n=39$ ) underwent a laparotomy with gynecological indications. These interventions were total abdominal hysterectomy + bilateral salpingo-oophorectomy ( $\mathrm{TAH}+\mathrm{BSO})$ in $61 \%$, only $\mathrm{TAH}$ in $22 \%$, and myomectomy in $16.7 \%$ in the control group and TAH + BSO in 57\%, only TAH in 33\%, myomectomy in $4.8 \%$, and salpingectomy in $4.8 \%$ in the treatment group.

Intragroup comparisons of the $3^{\text {rd }}$ month and $6^{\text {th }}$ month scores of the MVSS revealed that the scores of all parameters (height, pigmentation, vascularity, pliability, and total MVSS score) significantly decreased at the $6^{\text {th }}$ month evaluation as compared with the $3^{\text {rd }}$ month evaluation in all groups (control, silicone, and methylprednisolone groups) (Table 2).

Multiple group comparisons revealed that while there were no significant differences among the three groups in terms of the MVSS scores in any of the parameters at the $3^{\text {rd }}$ month evaluation, the MVSS scores of all parameters 


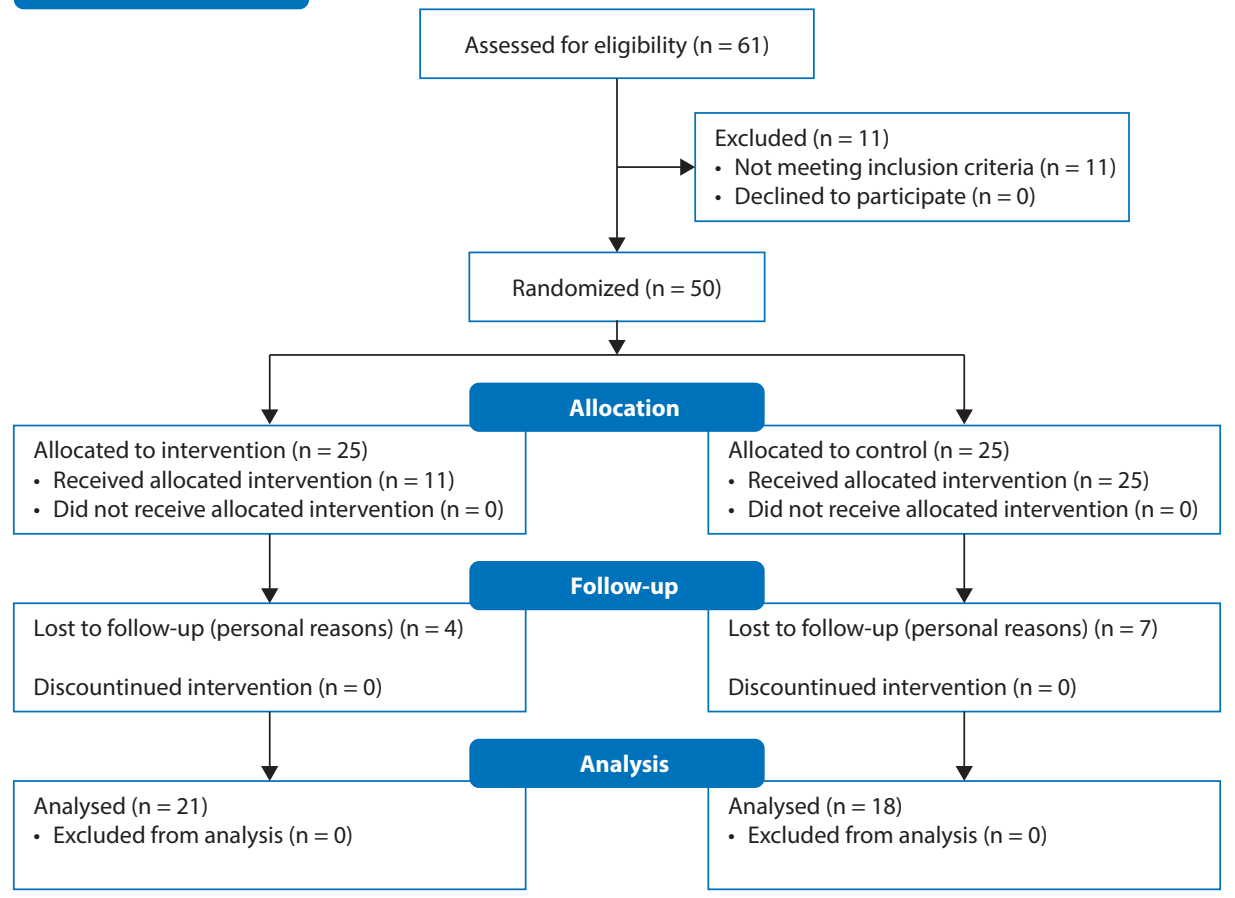

Figure 1. Patient flowchart

\begin{tabular}{|c|c|c|c|}
\hline & $\begin{array}{l}\text { Control group } \\
(n=18)\end{array}$ & $\begin{array}{l}\text { Treatment group } \\
\qquad(n=21)\end{array}$ & $\mathbf{p}$ \\
\hline Age (years) & $\begin{array}{l}43.44 \pm 5.99 \\
44.5(42-48)\end{array}$ & $\begin{array}{c}44.05 \pm 4.57 \\
45(42-47)\end{array}$ & 0.777 \\
\hline BMI $\left[\mathrm{kg} / \mathrm{m}^{2}\right]$ & $\begin{array}{c}25.4 \pm 3.29 \\
24.3(2)\end{array}$ & $\begin{array}{c}24 \pm 2.98 \\
23.7(2)\end{array}$ & 0.64 \\
\hline \multicolumn{4}{|l|}{ MVSS } \\
\hline Height & $\begin{array}{c}0.33 \pm 0.49 \\
0(0-1)\end{array}$ & $\begin{array}{c}0.38 \pm 0.50 \\
0(0-1)\end{array}$ & 0.760 \\
\hline Pigmentation & $\begin{array}{c}1.22 \pm 0.94 \\
2(0-2)\end{array}$ & $\begin{array}{l}1.38 \pm 0.86 \\
2(1-2)\end{array}$ & 0.608 \\
\hline Vascularity & $\begin{array}{c}2.89 \pm 0.58 \\
3(3-3)\end{array}$ & $\begin{array}{c}2.86 \pm 0.65 \\
3(2-3)\end{array}$ & 0.845 \\
\hline Pliability & $\begin{array}{c}1.50 \pm 0.51 \\
1.5(1-2)\end{array}$ & $\begin{array}{c}1.38 \pm 0.50 \\
1(1-2)\end{array}$ & 0.461 \\
\hline Total score & $\begin{array}{c}5.94 \pm 1.06 \\
6(5-7)\end{array}$ & $\begin{array}{c}6.00 \pm 0.95 \\
6(5-7)\end{array}$ & 0.976 \\
\hline
\end{tabular}

All data are presented as mean \pm standard deviation and median (Q1-Q3); BMI — body mass index, MVSS — modified Vancouver Scar Scale

significantly differed among the groups at the $6^{\text {th }}$ month evaluation ( $p<0.05$ for all; Table 2). Accordingly, subgroup analyses performed for the $6^{\text {th }}$ month evaluations demonstrated that the height and vascularity scores of the methyl- prednisolone group was significantly lower than those of the control and silicone groups $(p=0.002$ and $p=0.043$, respectively for height parameter and $p=0.014$ and $p=0.047$ for vascularity parameter). The pliability and total MVSS scores of the silicone and methylprednisolone groups were significantly lower than those of the control group $(p=0.026$ and $p=0.022$ for the pliability parameter and $p=0.049$ and $p=0.002$ for the total MVSS score). Moreover, the pigmentation score of the methylprednisolone group was significantly lower than those of the control and silicone groups ( $p=0.001$ and $p=0.197$, respectively). The pigmentation score of the silicone group was also significantly lower than that of control group ( $p=0.022$ ).

Changes in the scar scores assessed by the MVSS between the $3^{\text {rd }}$ and $6^{\text {th }}$ months in the study groups and their comparisons are presented in Table 3 and also in Figure 2. Multiple comparisons of the groups revealed that the change in the MVSS scores significantly differed among the three groups in all parameters $(p<0.05)$, except for the pigmentation parameter. Accordingly, subgroup analyses demonstrated significantly higher change in height score in methylprednisolone group than in the control and silicone groups ( $p=0.0001$ and $p=0.024$, respectively). The change in the height score was also significantly higher in the silicone group than in the control group $(p=0.041)$. The change in the vascularity score was significantly higher in the methylprednisolone group than in the control group 
Table 2. Scar assessment scores based on the modified Vancouver Scar Scale at the $3^{\text {rd }}$ and $6^{\text {th }}$ month follow-ups in the study groups and their comparisons

\begin{tabular}{|c|c|c|c|c|c|c|c|c|}
\hline & & \multicolumn{3}{|c|}{ Groups } & & & & \\
\hline & & $\begin{array}{l}\text { Control } \\
(n=18)\end{array}$ & $\begin{array}{l}\text { Silicone } \\
(n=21)\end{array}$ & $\begin{array}{l}\text { Methylprednisolone } \\
\qquad(\mathrm{n}=21)\end{array}$ & & & & \\
\hline & & $\begin{array}{c}\text { Mean } \pm \text { SD } \\
\text { Median (Q1-Q3) }\end{array}$ & $\begin{array}{c}\text { Mean } \pm \text { SD } \\
\text { Median (Q1-Q3) }\end{array}$ & $\begin{array}{c}\text { Mean } \pm \text { SD } \\
\text { Median (Q1-Q3) }\end{array}$ & $\mathbf{p}$ & p1 & p2 & p3 \\
\hline Height & & & & & & & & \\
\hline $3^{\text {rd }}$ month & & $\begin{array}{c}1.44 \pm 0.78 \\
1.5(1-2)\end{array}$ & $\begin{array}{c}1.43 \pm 0.6 \\
1(1-2)\end{array}$ & $\begin{array}{l}1.52 \pm 0.51 \\
2(1-2)\end{array}$ & 0.908 & - & - & - \\
\hline $6^{\text {th }}$ month & & $\begin{array}{c}1.17 \pm 0.62 \\
1(1-2)\end{array}$ & $\begin{array}{c}0.86 \pm 0.73 \\
1(0-1)\end{array}$ & $\begin{array}{c}0.48 \pm 0.68 \\
0(0-1)\end{array}$ & 0.008 & 0.161 & 0.002 & 0.043 \\
\hline & p & 0.025 & 0.0001 & 0.001 & & & & \\
\hline Pigmentation & & & & & & & & \\
\hline $3^{\text {rd }}$ month & & $\begin{array}{c}2.33 \pm 0.97 \\
3(1.75-3)\end{array}$ & $\begin{array}{l}1.9 \pm 0.7 \\
2(1-2)\end{array}$ & $\begin{array}{c}1.76 \pm 0.77 \\
2(1-2)\end{array}$ & 0.059 & - & - & - \\
\hline $6^{\text {th }}$ month & & $\begin{array}{l}1.78 \pm 0.94 \\
2(1-2.25)\end{array}$ & $\begin{array}{c}1.05 \pm 0.97 \\
1(0-2)\end{array}$ & $\begin{array}{c}0.67 \pm 0.8 \\
0(0-1)\end{array}$ & 0.003 & 0.022 & 0.001 & 0.197 \\
\hline & $\mathbf{p}$ & 0.004 & 0.001 & 0.0001 & & & & \\
\hline Vascularity & & & & & & & & \\
\hline $3^{\text {rd }}$ month & & $\begin{array}{c}2.22 \pm 0.88 \\
2.5(1-3)\end{array}$ & $\begin{array}{c}2.38 \pm 0.81 \\
3(2-3)\end{array}$ & $\begin{array}{c}2.19 \pm 0.81 \\
2(1.5-3)\end{array}$ & 0.706 & - & - & - \\
\hline $6^{\text {th }}$ month & & $\begin{array}{l}1.72 \pm 0.96 \\
2(1-2.25)\end{array}$ & $\begin{array}{c}1.52 \pm 1.17 \\
2(0-2.5)\end{array}$ & $\begin{array}{c}0.95 \pm 0.87 \\
1(0-1.5)\end{array}$ & 0.048 & 0.639 & 0.014 & 0.047 \\
\hline & $\mathbf{p}$ & 0.003 & 0.001 & 0.0001 & & & & \\
\hline Pliability & & & & & & & & \\
\hline $3^{\text {rd }}$ month & & $\begin{array}{l}1.89 \pm 0.9 \\
2(1-3)\end{array}$ & $\begin{array}{l}1.67 \pm 0.86 \\
2(1-2)\end{array}$ & $\begin{array}{l}1.62 \pm 0.81 \\
2(1-2)\end{array}$ & 0.561 & - & - & - \\
\hline $6^{\text {th }}$ month & & $\begin{array}{l}1.56 \pm 0.78 \\
2(1-2)\end{array}$ & $\begin{array}{c}0.95 \pm 0.81 \\
1(0-2)\end{array}$ & $\begin{array}{c}0.9 \pm 1 \\
1(0-1.5)\end{array}$ & 0.035 & 0.026 & 0.022 & 0.670 \\
\hline & $\mathbf{p}$ & 0.014 & 0.001 & 0.001 & & & & \\
\hline Total score & & & & & & & & \\
\hline $3^{\text {rd }}$ month & & $\begin{array}{l}7.61 \pm 2.99 \\
9(5-10)\end{array}$ & $\begin{array}{c}7.29 \pm 2.19 \\
8(5.5-9)\end{array}$ & $\begin{array}{c}6.95 \pm 2.33 \\
7(5.5-9)\end{array}$ & 0.523 & - & - & - \\
\hline $6^{\text {th }}$ month & & $\begin{array}{c}6.11 \pm 2.74 \\
6.5(4.75-8.25)\end{array}$ & $\begin{array}{c}4.29 \pm 2.97 \\
5(1-7)\end{array}$ & $\begin{array}{l}3 \pm 2.81 \\
3(0.5-4)\end{array}$ & 0.006 & 0.049 & 0.002 & 0.136 \\
\hline & p & 0.0001 & 0.0001 & 0.0001 & & & & \\
\hline
\end{tabular}

SD - standard deviation, Q1 $-25^{\text {th }}$ percentile, Q3 $-75^{\text {th }}$ percentile; $\mathrm{p} 1-$ control group vs. silicone group; $\mathrm{p} 2-$ control group vs. cortisone group; $\mathrm{p} 3-$ silicone group vs. cortisone group

$(p=0.004)$. The changes in the pliability and total scores of the methylprednisolone and silicone groups were significantly higher than that of the control group $(p=0.016$ and $p=0.01$, respectively for pliability and $p=0.001$ and $p=0.022$ for total score). There were no significant differences between the silicone and methylprednisolone groups in terms of the changes in the vascularity, pliability, and total MVSS score $(p=0.219, p=0.885$, and $p=0.167$, respectively).

Figure 3 shows the appearance of the scar from each group at baseline, at the end of the $3^{\text {rd }}$ and 6 -months. None of the patients experienced side effects during treatment period.
Evaluation of the patient satisfaction at the $6^{\text {th }}$ month follow-up revealed similar satisfaction scores in methylprednisolone and silicone groups (3.33 \pm 0.73 [median, 3, Q1-Q3, 3-4] and $2.95 \pm 0.87$ [median, 3, Q1-Q3, 2-4], respectively; $p=0.116)$. In the present study, $11 \%$ of the patients in the control group, $33 \%$ of the patients in the silicone group, and $48 \%$ of the patients in the methylprednisolone group were very satisfied. The rate of patient satisfaction was significantly higher in the methylprednisolone group than in the control group $(p=0.001)$. No significant difference was found in terms of patient satisfaction between the control and silicone groups $(p=0.21)$ and between the silicone and methylprednisolone groups $(p=0.05)$ (Table 4). 


\begin{tabular}{|c|c|c|c|c|c|c|c|}
\hline \multirow{3}{*}{$\begin{array}{l}\text { Change }(\%) \text { in the MVSS } \\
\text { scores between } 3^{\text {rd }} \text { and } \\
6^{\text {th }} \text { months }\end{array}$} & \multicolumn{3}{|c|}{ Groups } & \multirow[b]{3}{*}{$\mathbf{p}$} & \multirow[b]{3}{*}{ p1 } & \multirow[b]{3}{*}{ p2 } & \multirow[b]{3}{*}{ p3 } \\
\hline & \multirow{2}{*}{$\begin{array}{c}\begin{array}{c}\text { Control } \\
(n=18)\end{array} \\
\text { Mean } \pm \text { SD } \\
\text { Median (Q1-Q3) }\end{array}$} & \multirow{2}{*}{$\begin{array}{c}\begin{array}{c}\text { Silicone } \\
(\mathrm{n}=\mathbf{2 1})\end{array} \\
\text { Mean } \pm \text { SD } \\
\text { Median (Q1-Q3) }\end{array}$} & \multirow{2}{*}{$\begin{array}{l}\text { Methylprednisolone } \\
(\mathbf{n}=\mathbf{2 1 )} \\
\text { Mean } \pm \text { SD } \\
\text { Median (Q1-Q3) }\end{array}$} & & & & \\
\hline & & & & & & & \\
\hline Height & $\begin{array}{c}12.96 \pm 21.81 \\
10(0-37.5)\end{array}$ & $\begin{array}{c}40.48 \pm 43.64 \\
50(0-100)\end{array}$ & $\begin{array}{l}71.43 \pm 40.53 \\
100(50-100)\end{array}$ & 0.001 & 0.041 & 0.0001 & 0.024 \\
\hline Pigmentation & $\begin{array}{c}44.44 \pm 29.7 \\
50(25-66.67)\end{array}$ & $\begin{array}{c}55.56 \pm 38.85 \\
50(16.67-100)\end{array}$ & $\begin{array}{c}68.25 \pm 40.79 \\
100(41.67-100)\end{array}$ & 0.129 & - & - & - \\
\hline Vascularity & $\begin{array}{l}25.93 \pm 32.95 \\
16.67(0-37.5)\end{array}$ & $\begin{array}{l}45.24 \pm 41.21 \\
33.33(0-100)\end{array}$ & $\begin{array}{c}59.52 \pm 35.58 \\
66.67(33.33-100)\end{array}$ & 0.021 & 0.147 & 0.004 & 0.219 \\
\hline Pliability & $\begin{array}{l}15.74 \pm 27.1 \\
10(0-33.33)\end{array}$ & $\begin{array}{c}46.83 \pm 40.7 \\
50(0-100)\end{array}$ & $\begin{array}{c}49.21 \pm 44.87 \\
50(0-100)\end{array}$ & 0.019 & 0.01 & 0.016 & 0.885 \\
\hline Total score & $\begin{array}{c}24.89 \pm 29.54 \\
14.29(10-34.09)\end{array}$ & $\begin{array}{c}46.85 \pm 35.93 \\
36.36(22.22-90)\end{array}$ & $\begin{array}{c}60.15 \pm 29.69 \\
57.14(36.67-87.5)\end{array}$ & 0.002 & 0.022 & 0.001 & 0.167 \\
\hline
\end{tabular}

MVSS - modified Vancouver Scar Scale; SD - standard deviation; Q1 - 25 th percentile; Q3 $-75^{\text {th }}$ percentile; $\mathrm{p} 1$ - control group vs. silicone group; $\mathrm{p} 2-$ control group vs. cortisone group; $\mathrm{p} 3$ - silicone group vs. cortisone group.

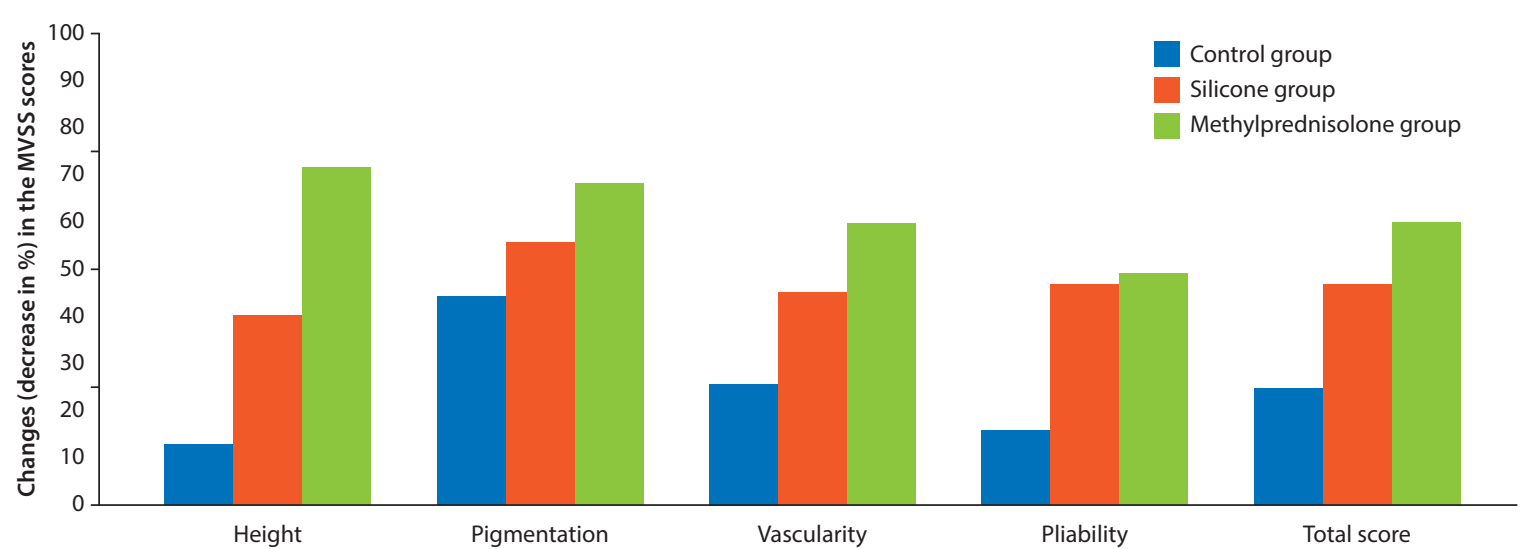

Figure 2. Changes (decreases in percentages) in the scar scores assessed by the modified Vancouver Scar Scale (MVSS) between the $3^{\text {rd }}$ and $6^{\text {th }}$ months

\section{DISCUSSION}

Wound healing includes several steps, consisting of the inflammatory, tissue-formation, and tissue-remodeling phases [11]. To date, fibroblast activity, extracellular matrix components, growth factors, cytokines, and other mechanisms have been investigated as possible factors responsible for scar formation [12].

In this study, we evaluated the uses of topical silicone gel and corticosteroid cream versus no treatment for preventing surgical scar formation in terms of both efficacy and convenience. We preferred topical administration of corticosteroids in cream form to decrease any potential side effects and used the same route for silicone gel and corticosteroid cream for comparison. In addition, we thought that we could enhance patient compliance with a noninvasive, painless, and easily applied treatment.
Various mechanisms have been proposed as possible modes of action for silicone-based agents and corticosteroids in the wound healing processes including: 1) an increased temperature or oxygen tension increasing collagenase activity and leading to collagen breakdown shrinking the scars [3, 7], 2) occlusion and hydration of wounds [7, 13]; reduction in transepidermal water loss decreases stimulation of keratinocytes which stops cytokine production [13], and 3) polarization of the scar tissue caused by a negative static charge between silicone and skin [14] and the modulation of growth factors $[9,15,16]$.

Several studies have suggested topical silicone gel to be the first-line option for prevention of HS and keloids [7, 15-17]. In the study by Chan et al. [7] of 50 patients, sternal wounds were divided into two halves; one half was treated with silicone gel and the other half with placebo gel for 3 mon- 
A

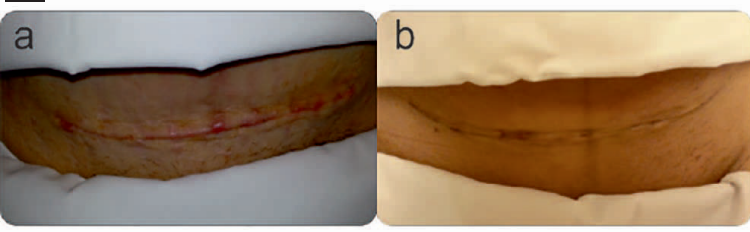

B

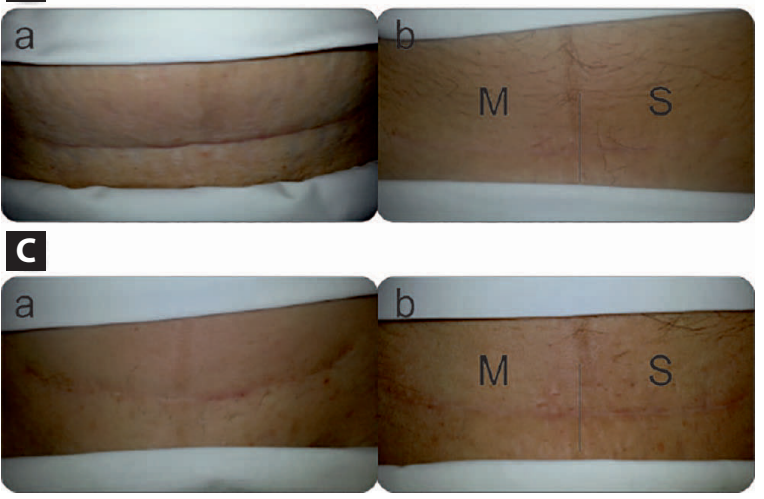

Figure 3. A. Appearance of the scar on the $10^{\text {th }}$ postoperative day of a patient in the (a) control group and (b) treatment group. Note the red to purple, hyperpigmented appearance; $\mathbf{B}$. Appearance of the scar at the end of the $3^{\text {rd }}$ month of a patient in the (a) control group and (b) treatment group; $\mathbf{C}$. Appearance of the scar at the end of the $6^{\text {th }}$ month of a patient in the (a) control group and (b) treatment group. Note that the better external appearance, the decreased erythema and reduced irregular texture are distinct in the methylprednisolone cream applied side. $\mathrm{M}$ - methylprednisolone cream applied side and S — silicone gel applied side

ths. In that study, silicone gel was associated with a significant reduction in the scores for scar pigmentation, vascularity, pliability, height, pain, itchiness ( $p \leq 0.02$ ), assessed by Vancouver Scar Scale(VSS), and it was suggested as promising in preventing HS. In a recent study, Medhi et al. [18] investigated the efficacy of silicone gel in patients $(n=36)$ with recent surgical scars. After 3 months of treatment, significant improvements were observed in the height, pliability, and vascularity parameters ( $p=0.015, p=0.031, p=0.031$, respectively). Additionally, the investigator was completely satisfied with the scar healing in $71.4 \%$ patients. In a study by Kong et al. [19], efficacy of topical silicone gel treatment on the surgical wounds of patients $(n=100)$ undergoing total knee arthroplasty was investigated. Postoperative 3 months, 6 months and 1 year evaluations revealed no significant difference between the silicone and placebo gel groups regarding VSS components at the postoperative $3^{\text {rd }}$ month, only pigmentation and height components were significantly lower in the silicone gel group than placebo gel group at postoperative 6 months and 1 year. In our study, MVSS scores of all parameters were reduced at the $6^{\text {th }}$ month evaluation as compared to the $3^{\text {rd }}$ month in silicone group. While there was no significant difference between the control and silicone groups in any MVSS parameter at the $3^{\text {rd }}$ month evaluation, it was observed that the pigmentation, pliability, and total MVSS scores were significantly lower in silicone group than in the control group at the $6^{\text {th }}$ month evaluation. When evaluated regarding the changes in MVSS scores between the $3^{\text {rd }}$ and $6^{\text {th }}$ months in the study groups, the changes in the height, pliability, and total MVSS scores were significantly higher in silicone group than in the control group.

The severity of inflammation and type of immune response predisposes individuals to excessive scar formation [1]. The effects of corticosteroids are mainly owing to their suppressive effects on the inflammatory process and also due to decreases in collagen and glycosaminoglycan synthesis and increases in collagen and fibroblast degeneration [20]. Intralesional corticosteroid injection is widely accepted for the management of HS and keloids [3-6, 8]. The injection causes reductions in the scar volume and results in an improvement in the scar pliability, height, and symptoms. Owing to poor tissue absorption, intralesional injections are preferred in mature scars [21]. Intralesional corticosteroid injection is recommended at the end of 6 months for patients with postoperative linear scars who fail to respond to prophylactic treatments in the first 6 months postoperatively and having ongoing $\mathrm{HS}$ [5, 6, 22-24]. In the present study, however, instead of intralesional corticosteroid injection, we aimed to evaluate a novel approach in which a corticosteroid in cream form was used in fresh wounds at the postoperative early period when absorption is good. To the best of our knowledge, this is the first study to compare the use

Table 4. Evaluation of patient satisfaction at the end of the $6^{\text {th }}$ month

\begin{tabular}{|l|c|c|c|c|c|c|}
\hline & $\begin{array}{c}\text { Control group } \\
(\mathbf{n}=\mathbf{1 8})\end{array}$ & $\begin{array}{c}\text { Silicone group } \\
(\mathbf{n}=\mathbf{2 1 )}\end{array}$ & $\begin{array}{c}\text { Methylprednisolone group } \\
(\mathbf{n}=\mathbf{2 1 )}\end{array}$ & $\mathbf{p 1}$ & $\mathbf{p 2}$ \\
\hline Satisfaction, $\mathrm{n}(\%)$ & & & $1(4)$ & & \\
\hline Unsatisfied & 0 & $1(5)$ & 0 & 0.21 & $\mathbf{0 . 0 0 1}$ & 0.05 \\
\hline Slightly satisfied & $7(39)$ & $5(24)$ & $10(48)$ & \\
\hline Satisfied & $9(50)$ & $8(38)$ & $10(48)$ & \\
\hline Very satisfied & $2(11)$ & $7(33)$ & & \\
\hline
\end{tabular}

p1 - control group vs. silicone group; p2 - control group vs. cortisone group; p3 - silicone group vs. cortisone group 
of methylprednisolone in topical cream form with topical silicone gel in the early postoperative period regarding scar prevention and patient satisfaction.

According to a Cochrane Collaboration Review in 2013, no prevention studies were identified comparing silicone gel treatment and cortisone injection for preventing HS and keloids [25]. However, three studies comparing these products on the treatment arm were identified [26-28]. In their prospective randomized trial, Sproat et al. [26] treated one half of the hypertrophic sternal scars of 14 patients with triamcinolone acetonide injection and the other half with silicone gel sheets. They reported decreased scar height in both groups but an increase in scar width. The authors reported that the silicone gel sheets are associated with earlier symptomatic relief, a more esthetic scar appearance. However, participants in the triamcinolone injection group experienced complications, including pain, skin atrophy, pigmentary changes. Accordingly, they suggested silicone gel as treatment of choice for symptomatic HS. In the study by Tan et al. [27], 16 of 17 patients treated with intralesional injections of triamcinolone acetonide had a significant reduction in the size of keloids and thus the authors suggested this method as the primary treatment for keloids. Kelemen et al. [28] reported that the intralesional steroid injection led to a greater improvement of MVSS as compared to the silicone gel. In the present study, it was observed that the scores of all MVSS parameters were significantly reduced in methylprednisolone group at the $6^{\text {th }}$ month evaluation as compared to the $3^{\text {rd }}$ month. While there was no significant difference between methylprednisolone and control groups in any MVSS parameter at the $3^{\text {rd }}$ month evaluation, the scores of all MVSS parameters at the $6^{\text {th }}$ month evaluation were significantly lower in methylprednisolone group than in the control group. Additionally, evaluation of the changes in MVSS scores between the $3^{\text {rd }}$ and $6^{\text {th }}$ months also revealed that the decreases in all scores of MVSS parameters were significantly higher in methylprednisolone group than in the control group. Comparison of the methylprednisolone and silicone groups at the $6^{\text {th }}$ month evaluation revealed that the scores of height, pigmentation, and vascularity parameters of the methylprednisolone group were significantly lower in the silicone group. On the other hand, evaluation of the changes in the MVSS scores between the $3^{\text {rd }}$ and $6^{\text {th }}$ months revealed that only the change in the height score was significantly higher in the methylprednisolone group than in the silicone group. In contrast to intralesional corticosteroid injection, none of the patients in treatment groups experienced side effects during the treatment.

Silicone gel treatment has been successfully employed for prevention of HS and keloid formation on different parts of the body [7, 18, 28, 29]; however, it was not very effective on the Pfannenstiel incisions in our study. This could be due to the incision site at which HS and keloid formations are less common than in the other parts of the body.

In the present study, patient satisfaction with the treatments was also evaluated at the $6^{\text {th }}$ month. It was observed that the patients in silicone group were "very satisfied"by 33\%, the patients in methylprednisolone group were "very satisfied" by $48 \%$, and the patients in the control group were"very satisfied" by $11 \%$. In the study by Medhi et al. [17], the rate of patients who were "completely satisfied" or "satisfied" with the treatment was 54\%. Sepehrmanesh [30] reported that $69.8-85 \%$ of the patients rated the improvement by silicone gel as "good" or "very good". In the present study, the rate of satisfaction was significantly higher in methylprednisolone group than in the control group $(p=0.001)$. We believe that patients did not experience any side effect related to methylprednisolone cream and did not feel height and/or swelling at the site of incision might positively affect their satisfaction.

There are many factors that may contribute to scar overgrowth [14]. In this study, we attempted to eliminate these variables by choosing the same anatomical region of the same participant for treatments. Moreover, we also ensured using the same materials by the same surgeon and eliminated any surgeon-related risk factors for wound healing.

The present study has some limitations. First, it was impossible to exactly monitor how the patients used the gel or cream on their wounds. Second is the small sample size and relatively short duration of treatment despite no definitive treatment duration in the literature. On the other hand, the strength of this study is that the study was designed as a prospective study and that evaluation of the same wound may eliminate the possibility of wound healing differences that could occur depending on the patients.

\section{CONCLUSIONS}

We demonstrated that there was no significant difference regarding the side effects and efficacy of the silicone gel and methylprednisolone cream. In addition, both agents in comparison failed to exhibit superiority over each other for preventing scar formation. However, the most prominent improvements occurred in the methylprednisolone group in all MVSS parameters as compared with the control group and in the height, vascularity, and pigmentation parameters as compared with the silicone group. Furthermore, patient satisfaction rate was higher also in the methylprednisolone group. In this context, the use of a topical methylprednisolone cream appears to be promising. Therefore, we believe that randomized controlled trials with larger sample sizes and longer follow-up periods are required. 


\section{Acknowledgments}

We are grateful to Dr. Sedat Arman, Prof. Dr. Aydın Saray and Prof. Dr. Ikbal Esen Aydingoz for their support in the present study.

\section{Conflicts of interest}

All authors have no conflicts of interest to declare (financial and/or non-financial).

\section{REFERENCES}

1. van der Veer WM, Bloemen MCT, Ulrich MMW, et al. Potential cellular and molecular causes of hypertrophic scar formation. Burns. 2009; 35(1): 15-29, doi: 10.1016/j.burns.2008.06.020, indexed in Pubmed: 18952381.

2. Brissett AE, Sherris DA. Scar contractures, hypertrophic scars, and keloids. Facial Plast Surg. 2001; 17(4): 263-272, doi: 10.1055/s-2001-18827, indexed in Pubmed: 11735059.

3. Arno Al, Gauglitz GG, Barret JP, et al. Up-to-date approach to manage keloids and hypertrophic scars: a useful guide. Burns. 2014; 40(7): 1255-1266, doi: 10.1016/j.burns.2014.02.011, indexed in Pubmed: 24767715.

4. Gold MH, Berman B, Clementoni MT, et al. Updated international clinical recommendations on scar management: part 1 - evaluating the evidence. Dermatol Surg. 2014; 40(8): 817-824, doi: 10.1111/ /dsu.0000000000000049, indexed in Pubmed: 25068543.

5. Gold MH, McGuire M, Mustoe TA, et al. International Advisory Panel on Scar Management. Updated international clinical recommendations on scar management: part 2 - algorithms for scar prevention and treatment. Dermatol Surg. 2014; 40(8): 825-831, doi: 10.1111/dsu.0000000000000050, indexed in Pubmed: 25068544.

6. Meaume S, Le Pillouer-Prost A, Richert B, et al. Management of scars: updated practical guidelines and use of silicones. Eur J Dermatol. 2014; 24(4): 435-443, doi: 10.1684/ejd.2014.2356, indexed in Pubmed: 25141160.

7. Chan KY, Lau CL, Adeeb SM, et al. A randomized, placebo-controlled, double-blind, prospective clinical trial of silicone gel in prevention of hypertrophic scar development in median sternotomy wound. Plast Reconstr Surg. 2005; 116(4): 1013-20; discussion 1021, indexed in Pubmed: 16163087

8. Poetschke J, Schwaiger H, Gauglitz GG, et al. Management of keloids and hypertrophic scars: current and emerging options. Clin Cosmet Investig Dermatol. 2013; 6: 103-114, doi: 10.2147/CCID.S35252, indexed in Pubmed: 23637546.

9. Ko WJ, Na YC, Suh BS, et al. The effects of topical agent (kelo-cote or contractubex) massage on the thickness of post-burn scar tissue formed in rats. Arch Plast Surg. 2013; 40(6): 697-704, doi: 10.5999/ /aps.2013.40.6.697, indexed in Pubmed: 24286041.

10. Forbes-Duchart L, Marshall S, Strock A, et al. Determination of inter-rater reliability in pediatric burn scar assessment using a modified version of the Vancouver Scar Scale. J Burn Care Res. 2007; 28(3): 460-467, doi: 10.1097/BCR.0b013E318053D3BB, indexed in Pubmed: 17438503.

11. Eming SA, Krieg T, Davidson JM. Inflammation in wound repair: molecular and cellular mechanisms. J Invest Dermatol. 2007; 127(3): 514-525, doi: 10.1038/sj.jid.5700701, indexed in Pubmed: 17299434.

12. Abergel RP, Pizzurro D, Meeker CA, et al. Biochemical composition of the connective tissue in keloids and analysis of collagen metabolism in keloid fibroblast cultures. J Invest Dermatol. 1985; 84(5): 384-390, indexed in Pubmed: 3998489.

13. Hirshowitz B, Lindenbaum E, Har-Shai $Y$, et al. Static-electric field induction by a silicone cushion for the treatment of hypertrophic and keloid scars. Plast Reconstr Surg. 1998; 101(5): 1173-1183, indexed in Pubmed: 9529199.

14. Tandara AA, Mustoe TA. The role of the epidermis in the control of scarring: evidence for mechanism of action for silicone gel. J Plast Reconstr Aesthet Surg. 2008; 61(10): 1219-1225, doi: 10.1016/j.bjps.2008.03.022, indexed in Pubmed: 18653391.

15. Shih R, Waltzman J, Evans GRD, et al. Plastic Surgery Educational Foundation Technology Assessment Committee. Review of over-the-counter topical scar treatment products. Plast Reconstr Surg. 2007; 119(3): 1091-1095, doi: 10.1097/01.prs.0000255814.75012.35, indexed in Pubmed: 17312518.

16. Berman B, Perez OA, Konda S, et al. A review of the biologic effects, clinical efficacy, and safety of silicone elastomer sheeting for hypertrophic and keloid scar treatment and management. Dermatol Surg. 2007; 33(11): 1291-302; discussion 1302, doi: 10.1111/j.1524-4725.2007.33280.x, indexed in Pubmed: 17958580.

17. Rhee SH, Koh SH, Lee DW, et al. Aesthetic effect of silicone gel on surgical scars in Asians. J Craniofac Surg. 2010; 21(3): 706-710, doi: 10.1097/SCS.0b013e3181d83fec, indexed in Pubmed: 20485033.

18. Medhi B, Sewal RK, Kaman L, et al. Efficacy and safety of an advanced formula silicone gel for prevention of post-operative scars. Dermatol Ther (Heidelb). 2013; 3(2): 157-167, doi: 10.1007/s13555-013-0036-8, indexed in Pubmed: 24254957.

19. Kong CG, Kim GH, Kim DW, et al. The effect of topical scar treatment on postoperative scar pain and pruritus after total knee arthroplasty. Arch Orthop Trauma Surg. 2014; 134(4): 555-559, doi: 10.1007/s00402-0141942-7, indexed in Pubmed: 24509938.

20. Boyadjiev C, Popchristova E, Mazgalova J. Histomorphologic changes in keloids treated with Kenacort. J Trauma. 1995; 38(2): 299-302, indexed in Pubmed: 7869456.

21. Widgerow $A D, C$ hait $L A$, Stals $R$, et al. New innovations in scar management Aesthetic Plast Surg. 2000; 24(3): 227-234, indexed in Pubmed: 10890953.

22. Middelkoop E, Monstrey S, Teot $L$, et al. Scar Management Practical Guidelines. Maca-Cloetens; 2011 pp. : 1-109.

23. Mustoe TA, Cooter RD, Gold MH, et al. International Advisory Panel on Scar Management. International clinical recommendations on scar management. Plast Reconstr Surg. 2002; 110(2): 560-571, indexed in Pubmed: 12142678.

24. Monstrey S, Middelkoop E, Vranckx JJ, et al. Updated scar management practical guidelines: non-invasive and invasive measures. J Plast Reconstr Aesthet Surg. 2014; 67(8): 1017-1025, doi: 10.1016/j.bjps.2014.04.011, indexed in Pubmed: 24888226.

25. O'Brien L, Jones DJ. Silicone gel sheeting for preventing and treating hypertrophic and keloid scars. Cochrane Database Syst Rev. 2013(9): CD003826, doi: 10.1002/14651858.CD003826.pub3, indexed in Pubmed: 24030657.

26. Sproat JE, Dalcin A, Weitauer N, et al. Hypertrophic sternal scars: silicone gel sheet versus Kenalog injection treatment. Plast Reconstr Surg. 1992; 90(6): 988-992, indexed in Pubmed: 1448534.

27. Tan E, Chua Sh, Lim J. Topical silicone gel sheet versus intralesional injections of triamcinolone acetonide in the treatment of keloids - a patient-controlled comparative clinical trial. Journal of Dermatological Treatment. 2009; 10(4): 251-254, doi: 10.3109/09546639909056040.

28. Kelemen $\mathrm{O}$, Hegedus $\mathrm{G}$, Kollár $\mathrm{L}$, et al. [A comparative clinical study of the treatment of hypertrophic scars with either intralaesional steroid or silicone gel sheeting]. Magy Seb. 2007; 60(6): 297-300, doi: 10.1556/MaSeb.60.2007.6.5, indexed in Pubmed: 18065368

29. Signorini M, Clementoni MT. Clinical evaluation of a new self-drying silicone gel in the treatment of scars: a preliminary report. Aesthetic Plast Surg. 2007; 31(2): 183-187, doi: 10.1007/s00266-005-0122-0, indexed in Pubmed: 17171514.

30. Sepehrmanesh M. Scar Management: observational study of 1522 patients using Kelo-cote, Silicone Gel. Komp Dermatologie. 2006; 1: 30-2. 